Quaternary International, 2016, 416, p. 177-182.

doi:10.1016/j.quaint.2015.09.006

\title{
An outlook on prehistoric research in Laos: An inventory and some perspectives
}

\section{Sommay Singthong}

Museum national d'Histoire naturelle, UMR 7194 CNRS-MNHN-UPVD, Department of History and Archaeology, Faculty of Social Sciences National University of Laos, P.O. Box 3722 Dongdok Campus, Xaithany District, Vientiane Capital, Lao Democratic People's Republic

\section{Valéry Zeitoun}

UMR 7207 (CR2P), CNRS-Upmc-Mnhn, Sorbonne universités, Université Pierre et Marie Curie, T. 46-56,

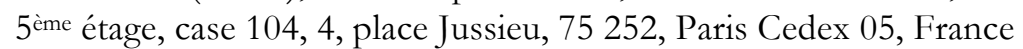

\section{Alain Pierret}

IRD, UMR 242 e Institute of Ecology and Environmental Sciences, Paris (BioPhys), National Agriculture and Forestry Research Institute, P.O. Box 4199, Ban Nongviengkham, Xaythany District, Vientiane, Lao Democratic People's Republic

\section{Hubert Forestier}

Muséum national d'Histoire naturelle, UMR 7194 CNRS-MNHN-UPVD, Institut de Paléontologie Humaine, 1 rue René-Panhard, 75013, Paris, France

\begin{abstract}
Prehistoric Research in Laos was initiated during the French Indochinese period. Disrupted by unstable geopolitics, Laotian teams started to revisit prehistoric cave sites and rock shelters in the early 2000s. International interest in Laotian prehistory resumed in 2005 with a prehistoric survey of Northern Laos focusing more especially, on ancient period (pre-) Hoabinhian lithic techno-complex but also, more recently on rock art along the Mekong river banks. The purpose of this paper is not to discuss the periods classically referred to as "recent prehistory" by authors, which generally spans from the Neolithic through to Metal ages and sometimes even historical times. Rather, we provide a retrospective on prehistoric investigations, in Laos to date, independently of periods, with the main focus on stone tools. New perspectives for prehistoric research in this widely under-explored country are briefly discussed.
\end{abstract}




\section{Introduction}

Between the end of the $19^{\text {th }}$ century and the SecondWorldWar, few archaeological investigations were conducted in Laos. In the late $19^{\text {th }}$ century, polished stones and metallic implements were collected in the Luang Prabang province during the "Mission Pavie" (1879-1895) (Massie, 1904). Mansuy (1920) conducted an archaeological survey and the excavation of Ban Don Tio cave (Fig. 1). These operations were subsequently managed by the Geological Service of Indochina, during the French Protectorate period (Fromaget, 1934, 1937a,b, 1940a, 1940b, 1941, 1952). During this period, Fromaget, Saurin and Colani became the most active and productive researchers involved in archaeological work in the region (Colani, 1932, 1935; Saurin, 1935, 1966, 1968; Fromaget, 1936, 1937a,b, 1940a,b, 1952; Fromaget and Saurin, 1936; Arambourg and Fromaget, 1938). Although some of the prehistoric sites discovered between the 1930s and the late 1960s have been revisited and further described (Sayavongkhamdy et al., 2000), the revival of Prehistory in Laos really only started in 2005, with the Middle Mekong Archaeological Project led by J. White (Marwick et al., 2009) focussing on the Luang Prabang area. This field program allowed this team to discover and excavate the Phou Phaa Khao rockshelter and Tham Vang Ta Leow cave where an original Hoabinhian industry was unearthed (White and Bouasisengpaseuth, 2008). Another survey was conducted in the vicinity of Vieng Phu Khra, Luang Nam Tha province (Northwestern Laos) in 2010 with the Laotian Department of History of the National Academy of Social Sciences, the French Institut de Recherche et Dévelopment and the Laotian Department of Archaeology of the Ministry of Culture and Communication (Zeitoun et al., 2012). This survey identified a new prehistoric site at the Ngeubhinh Mouxeu rock-shelter located northwest of Vieng Phu Khra. Other projects dealing with Prehistory, though focussing on rock art, appear to have potential to contribute to the development of prehistoric research and sustainable tourism in Laos. This however, is beyond the scope of this paper, which only deals with older Prehistoric periods. While Rock Art studies and Paleoanthropology arouse curiosity amongst the public, stone industries, while less sensational, are the prehistoric background of Laotian Prehistory.

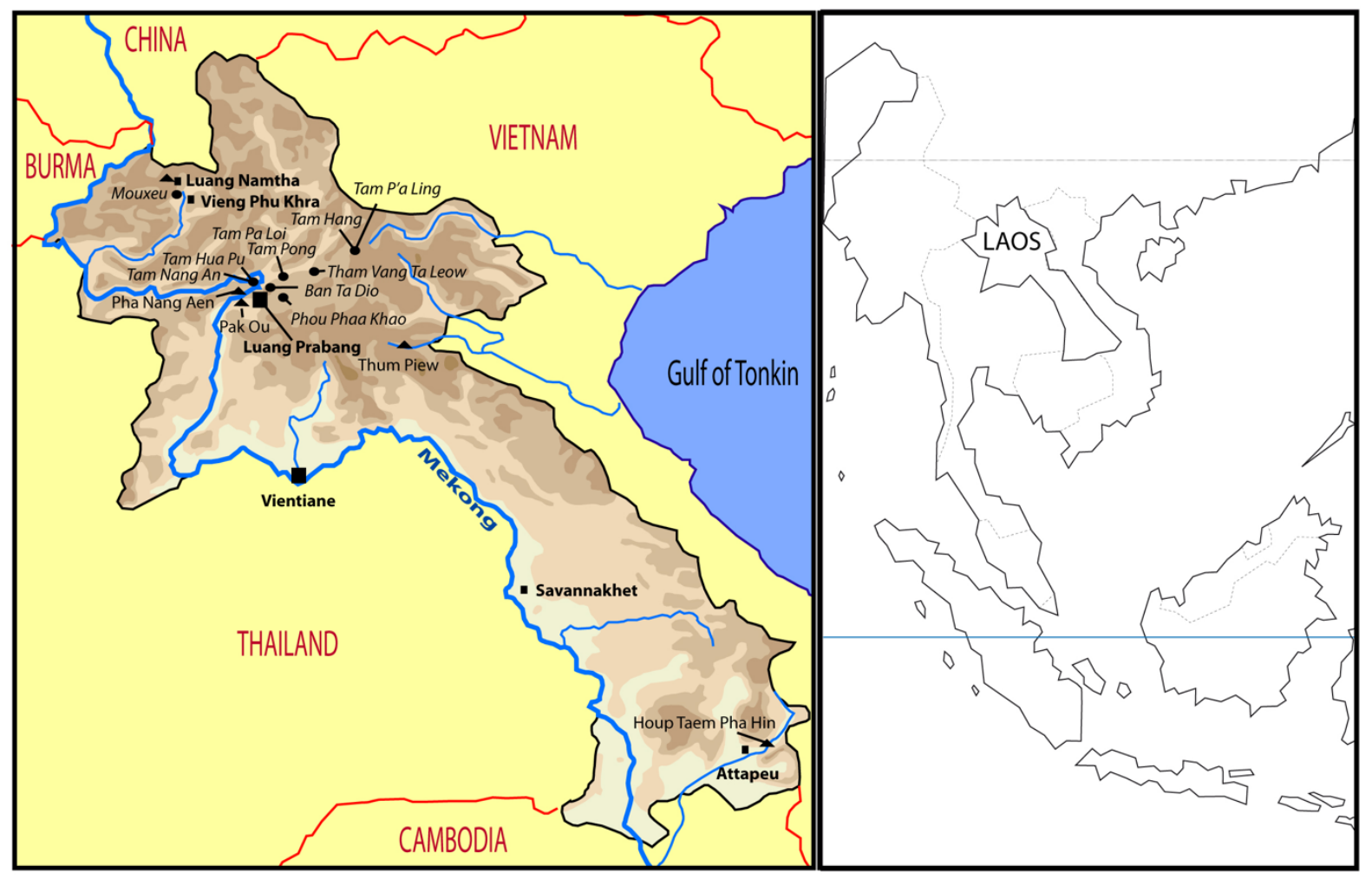

Fig. 1. Map of Laos with location of the sites referred to in the text. Round for prehistoric sites; triangle for rock-art sites

\section{Stone industries as the background of prehistory in Laos}

During the French Protectorate, prehistoric excavations were conducted at three sites in the Luang Prabang and Hu_a Pan provinces: Tam Pong in the Seuang basin, Tam Nang An, on the right bank of the Mekong river and Tam Hang in the Khan river catchment (Saurin, 1935, 1966; Fromaget and Saurin, 1936). These sites yielded Hoabinhian artefacts, polished tools and human remains. Polished stone tools uncovered in 
caves may date back to the Neolithic period even though most polished artefacts are present in more recent contexts of early Metal ages. Following this early prolific period of research in Laos, only a very few isolated Hoabinhian lithics and other prehistoric artifacts have been described (Sayavongkhamdy et al., 2000; Raymaekers, 2001). Previously discovered by Anzai (1976) on the right bank of the Mekong river at the foot of the Pu Luang mountain range, Tam Hua Pu was excavated in 1994-1995 (Sayavongkhamdy et al., 2000). Tam Hua Pu comprises Iron Age burials embedded in Hoabinhian deposits. Based on charcoal and shell analyses, this site was dated from $1340 \pm 70 \mathrm{~B}$ P to $32,500 \pm 900 \mathrm{~B}$ P. Nevertheless, the chronological series is not clearly linked to the archaeological artefacts and the authors only hypothesized that the Hoabinhian assemblage dated back to 4000 e $3500 \mathrm{~B}$ P without any clear supporting evidence of these dates. Due to the paucity of detailed and systematic prehistoric research in Laos, the Middle Mekong Archaeological Project (White and Bouasisengpaseuth, 2008) undertook an exploratory survey in 2005, which resulted in the finding of 58 archaeological sites in three Mekong tributary basins, upstream of Luang Prabang. Following this survey, the Phou Phaa Khao rockshelter and Tham Vang Ta Leow rockshelter were excavated in 2007 and 2008, respectively (Marwick et al., 2009). At Phou Phaa Khao, parts of seven human burials were uncovered in the deposit and the material recovered included thousands of stone flakes and cores with similarities to Hoabinhian technologies from Northwestern Thailand. At Tham Vang Ta Leow, abundant Hoabinhian cores and flakes were recovered from two test pits. Radiocarbon dates from the bases of the two pits indicate ages between $9450 \pm 60 \mathrm{~B}$ P to $9770 \pm 50 \mathrm{~B}$ P (White et al., 2009). More recently, in 2010, a survey was conducted in the vicinity of Vieng Phu Khra, Luang Nam Tha province, within the framework of the Project "Sedentism around the Mekong" funded by the French National Research Council (ANR), in partnership with the Laotian Department of History of the National Academy of Social Sciences and the Laotian Department of Archaeology of the Ministry of Culture and Communication. This partnership led to the discovery of the Ngeubhinh Mouxeu rock-shelter located $7 \mathrm{~km}$ northwest of Vieng Phu Khra (Zeitoun et al., 2012). The lithic material collected during the test pit excavations was rather scarce but allowed a precise diagnosis of the stone industry and brought to light information about the pre-Hoabinhian and Hoabinhian systems of lithic production. The objects discovered during these excavations are made on chert. They are all flakes, made by direct percussion with hard hammer. These flakes have partially cortical butts but some butts were also broken during the knapping process. Some of these flakes are tools. These pre-Hoabinhian stone tools were collected in and below sediments dated between 56,000 \pm 3000 and 45,000 \pm 2000 by OSL. Hoabinhian tools made with calcareous cobbles were found on the rock-shelter's floor, near the excavation. Two of these pieces had a relatively thick, elongated and rather quadrangular morphology while another one was an original convergent tool. One unifacial tool of plano-convex section displayed a classic Hoabinhian morphology and another tool, derived from an oval-shaped cobble had noticeable sharp edges on both sides and distal edge. Partially and fully polished stone tools associated to flaked Hoabinhian tools were discovered at Tam Hang (Fromaget, 1936, 1940a, 1940b; Arambourg and Fromaget, 1938) in Hu_a Phan province and at Tam Pong (Saurin, 1966) in Luang Prabang province. Excavations at Tam Hang site have been conducted on an annual basis for about ten years as part of the Mission Archéologique et Paléontologique au Laos (Bacon, 2012). This site's lithic assemblage, reportedly belonging to the Hoabinhian tradition, includes large stone tools, flakes, nd cores from which tools appear to have been made by direct percussion with a hard hammer (Demeter et al., 2009). Charcoals from the two main cultural layers described at Tam Hang South by Fromaget and Saurin (1936) have been dated between $7080 \pm 25$ B P and 11,625 \pm $35 \mathrm{~B} \mathrm{P}$ in one test-pit, and between 10,070 $\pm 40 \mathrm{~B} \mathrm{P}$ and 13,215 $\pm 45 \mathrm{~B} \mathrm{P}$ in a second one, and between $9380 \pm 40 \mathrm{~B}$ P and $9775 \pm 35 \mathrm{~B}$ P at Tam Hang Central (Bacon, 2012). Stone toolswere also recovered fromTam Hang North where the third, undated layer, corresponds to the lower layer of Tam Hang South according to Fromaget and Saurin (1936 p.35).

\section{Rock art in Laos}

\section{Perspectives to develop prehistory in Laos}

Rock art generally concerns Metal Ages or even more recent periods but, as it is an effectiveway to develop awareness about and interest in archaeology amongst the public, we provide a short overview of Rock art in Laos. Very little is known about rock art in Laos, particularly when compared to the neighbouring countries Thailand, Vietnam and Cambodia (Tan, 2014). There is a lack of published information about Laotian rock art, which has only recently been exposed publicly by Bouxaythip (2011) at aworkshop hosted by SEAMEO-SPAFA. Thanks to the work of this author, we are now aware of the existence, in Xayabouli Province, Northeastern Laos, of an unnamed site containing petroglyphs of pecked anthropomorphic and zoomorphic figures and cupules. Another site in the Northern Luang Namtha province includes a red (in 
the web version) painting of an anthropomorph in spread-eagle position (Fig. 2). It is also known that three rock art sites are located along the Ou River in Luang Prabang Province. The Pak Ou caves also provide some prehistoric and historic rock art (Tan and Taçon, 2014) and Srisuchat (1996) mentioned a painted cliff at Pha Nang Aen, which is located near the Pak Ou caves. Red painting is only indicated at Thum Piew in Xiengkouang province and at Houp Taem Pha Hin in Attapeu province according to Phaboudy (2009). It is expected that, in the near future, a documented catalogue of the known prehistoric paintings will be compiled and will include baseline information for the development of newexploratory field programs. Such programs will also help to draw the attention of the public and authorities on the sustainable exploitation of the prehistoric heritage of Laos.

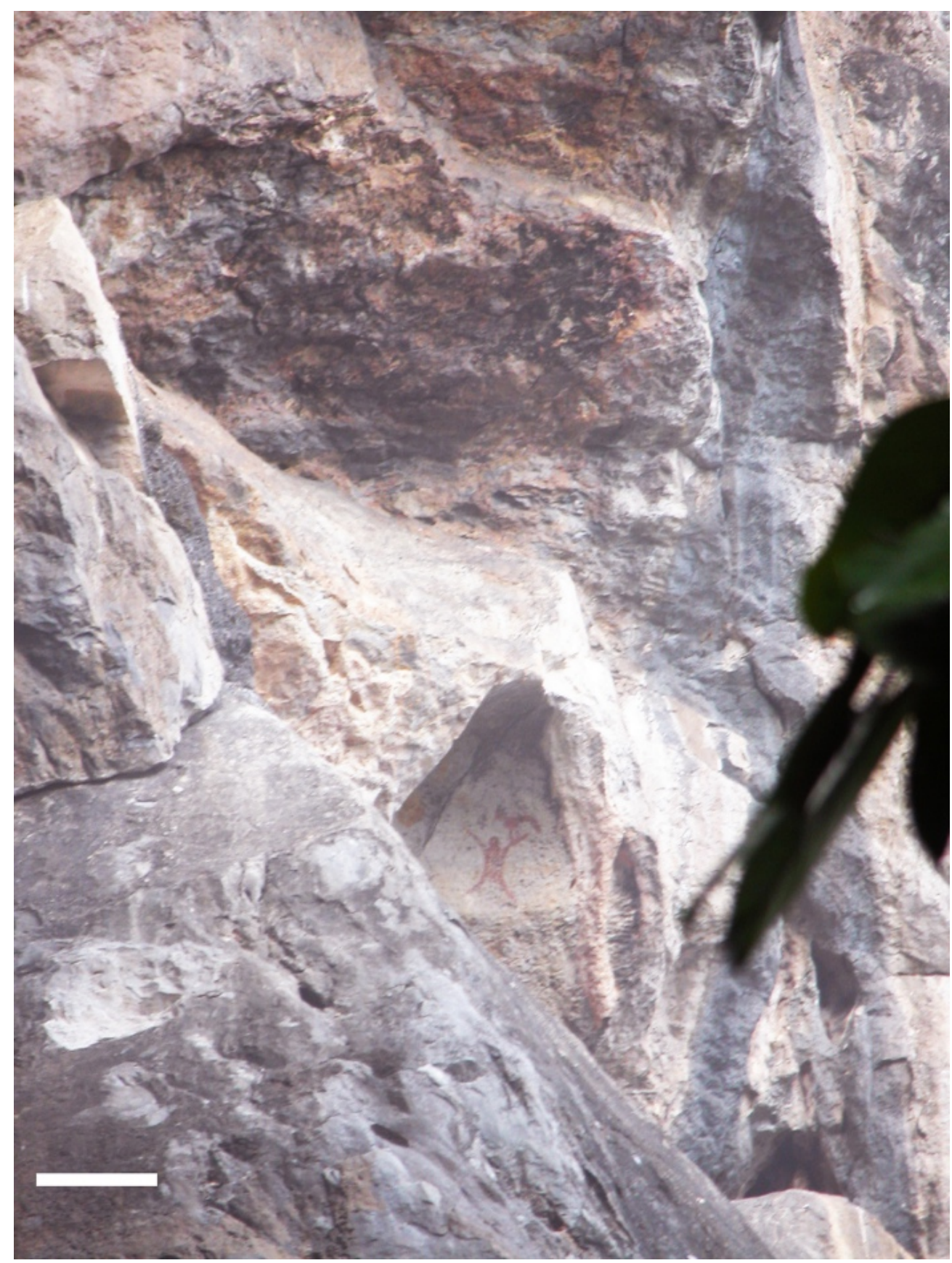

Fig. 2. Isolated anthropomorphic painting in Luang Nam Tha province. The scale on the picture is $15 \mathrm{~cm}$ (picture V. Zeitoun). 


\section{Old human remains in Laos}

Data on human remains from Prehistoric periods are extremely rare in Laos but it is a very sensitive subject both for the public and for the authorities. If Rock art appears to be a newsubject of interest in Laos, there is a little background concerning paleoanthropology. Thus, a lower M2 of so-called "Sinanthropus" (id est Homo erectus), without its root, was uncovered at Tam P'a Loi from within a layer that also included Pongo fossils teeth according to Fromaget and Saurin (1936) and Fromaget (1940a). Arambourg and Fromaget (1938) also reported the presence of a fragment of a right temporal human ("Sinanthropus") bone at the bottom of the lowest faunal bearing layer of Tam Hang North. A partial calvaria associated with several teeth and an infant clavicula were uncovered from the calcareous blocks found at the bottom of the Mesolithic bed at Tham Hang South. The fragments of this juvenile calvaria (posterior part of the frontal bone, left parietal, partial right parietal and occipital without basis) are very thin, contrary to the assessment of Olsen and Ciochon (1990). Displaying an occipital bun, flattened lambdaic area, a light collapse of the parietal bones back to the bregma and a slight lower receding forehead, it was identified as "neandertaloid" by Arambourg and Fromaget (1938). Nevertheless, in spite of no real evidence (Fig. 3), Fromaget (1940a) suggested that, from the shape of its calotte, it might be more closely related to a juvenile Homo modjokertoensis (id est Homo erectus). These human remains are conserved at the Mus_ee de l'Homme in Paris, France, awaiting further analysis. Fromaget excavated human skeletons from both TamHang South and Tam Hang North (Fromaget, 1936, 1940a,b). These modern human skeletons were interred alongside the wall of the rockshelter and clearly belonged to burials as described in Fromaget and Saurin (1936). At least six burials on an ash bedwere described at Tam Hang South and four individuals at Tam Hang North. At the Tam Pong rock shelter, close to Na-Pho and Ban Pa Long Nga villages, in Luang Prabang province, burials seem to be related to the same cultural context. With the support of the Program GDR 450 Asie du Sud-est led by M. Santoni and C. Falguères, the individual number 1 of Tam Pong curated at Mus_ee de l'Homme was directly radiocarbon dated to $5380 \pm 60 \mathrm{~B}$ P (Demeter, 2000).

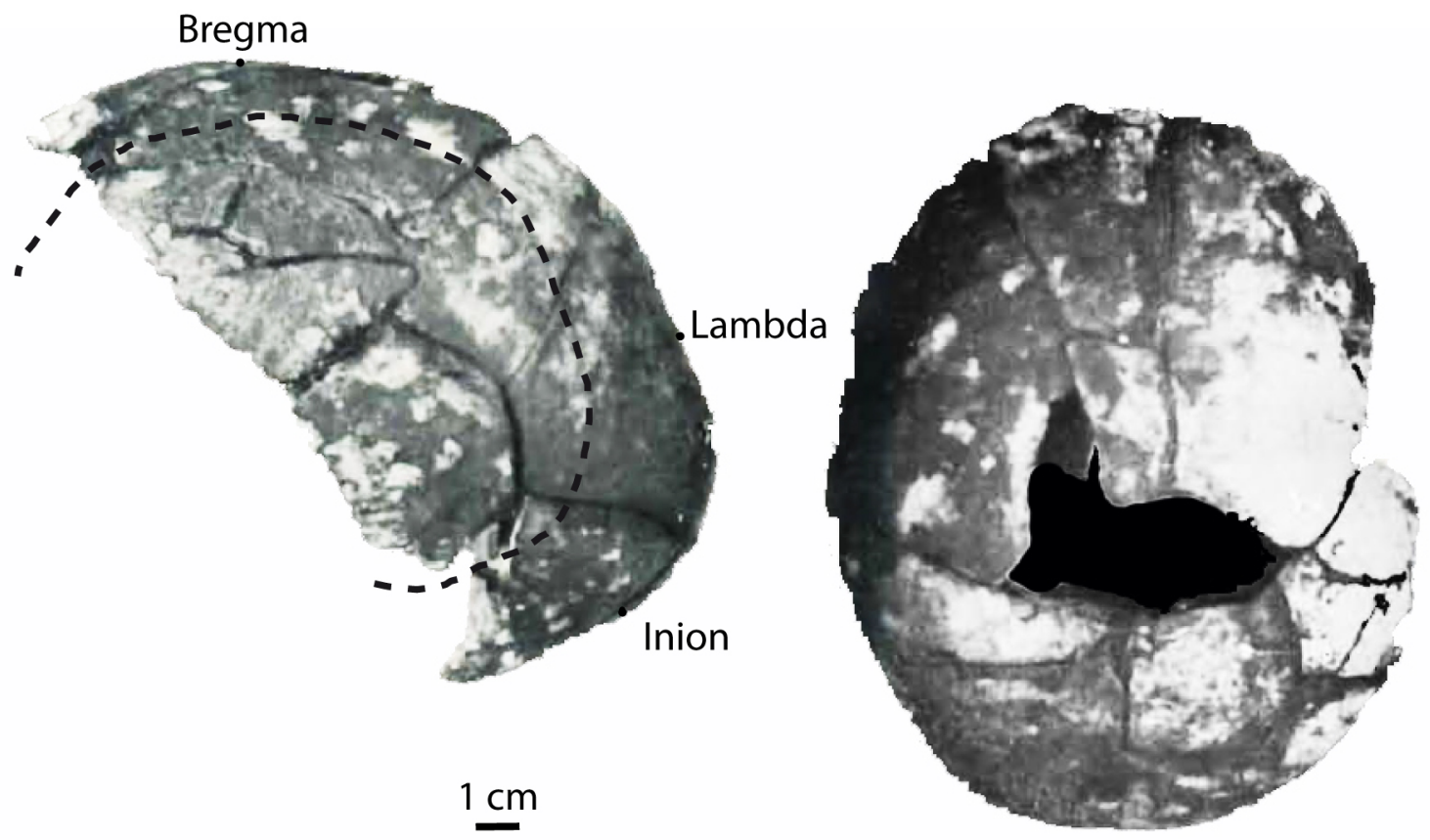

Fig. 3. Juvenile calvaria of Tam Hang modified from Fromaget (1940a) with the shape of the profile of Modjokerto calvaria indicated by the dotted-line.

Another fossil curated at the Musée de l'Homme is the individual THS 10 found at Tam Hang South by Fromaget. Thanks to the same program, THS 10 was dated to $15,740 \pm 80 \mathrm{~B} \mathrm{P}$ which represents an unresolved stratigraphic incongruity as i) Bacon (2012) reported a maximum age of $13,215 \mathrm{~B}$ P at $3.25 \mathrm{~m}$ and ii) Fromaget and Saurin (1936) clearly indicated that the Tam Hang South excavation was stopped at $1.60 \mathrm{~m}$. A similar incongruity concerns the paleoanthropological remains recently uncovered from the neighbouring cave Tam P'a Ling, as pointed out by Pierret et al. (2012) and discussed further by Kuzmin and Keates (2014). The intrusive position of TPL1 modern human remains direct-dated to $63.6 \mathrm{ka}$ in sediment dated between $46 \mathrm{ka}$ (OSL) and $2.77 \mathrm{ka}$ (AMS ${ }^{14} \mathrm{C}$ ) still awaits a convincing depositional explanation (Fig. 4). 


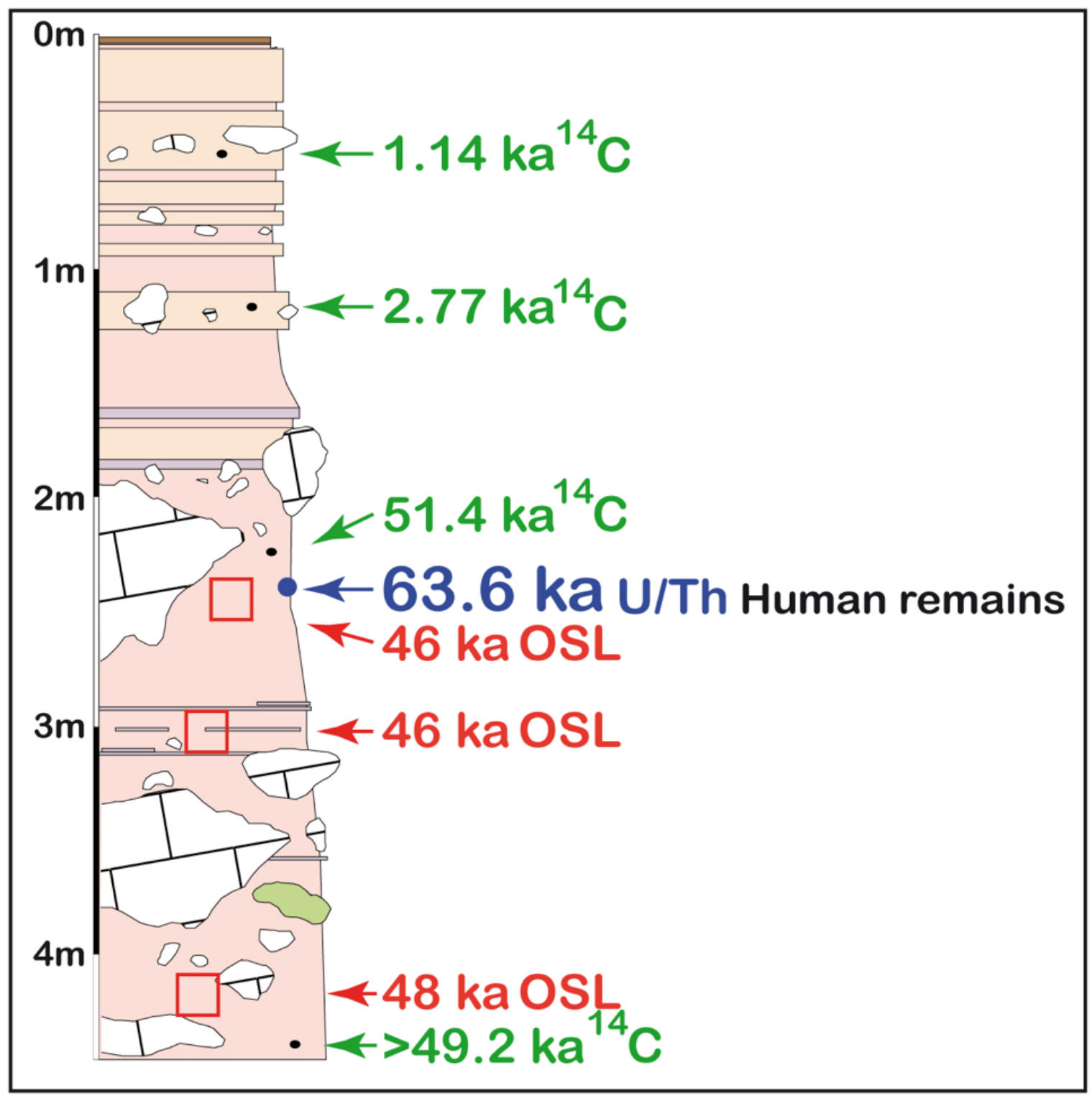

Fig. 4. Intrusive position of TPL1 modern human remains at Tam P'a Ling modified from Pierret et al. (2012).

\section{Conclusion}

In this paper, we show that the development of Laotian prehistory has progressed along a dual path. On the one hand, the first path consists of re-excavating and re-assessing sites discovered and described before World War II (Sayavongkhamdy et al., 2000; Bacon, 2012). On the other hand, new sites have recently been discovered thanks to exploratory surveys (White and Bouasisengpaseuth, 2008; Zeitoun et al., 2012). While both approaches are needed and complementary, the scale at which they have been conducted to date is far from sufficient. Further, investigations to date only concern the provinces that have, historically, already yielded prehistoric material, Northern Laos. Being centrally located between Vietnam and Northern Thailand, the mountainous regions of Northern Laos should help shed new light on a Prehistory that has received very little attention since the French Protectorate period. Few ancient modern human remains and pre-Hoabinhian stone artefacts are known in Laos, as is the case in mainland Southeast Asia as a whole. The fact that mountainous Northern Laos has received more attention recently certainly arises from the rediscovery of the prehistoric potential of Laos, which has been historically recognized. Recent work has merely resumed or complemented research in regions where the Laotian prehistoric potential was already been found and described. As a benchmark of the regional prehistoric background, a number of Hoabinhian stone assemblages corresponding to hunteregatherer sites have been recovered from karst contexts of mainland Southeast Asia, notably in Vietnam, Thailand and Cambodia. In the vicinity of northwestern Laos, near the Burmese boundaries, northern Thai Hoabinhian sites have been dated from $3700 \pm 30 \mathrm{~B}$ P at Huai 
Hin near the Salaween riverbank (Forestier et al., 2005) and 26,580 250 B P at Tham Lod in Mae Hong Son province (Shoocongdej, 2006). In southern Thailand reexcavation of the Moh Khiew site yielded dates from $9470 \pm 420 \mathrm{~B}$ P to 11, $220 \pm 510 \mathrm{~B}$ P for the Hoanihnian layers (Auetrakulvit et al., 2012) and ongoing excavations at Laang Spean Cave in Cambodia indicate dates ranging from $5018 \pm 29$ B P to 10,042 \pm 43 B P (Forestier et al., 2015). In Vietnam, the most reliable chronology of Hoabinhian sites is that of Yi et al. (2008) at Hang Cho, with dates from $8430 \pm 180 \mathrm{~B}$ P to 19,560 $\pm 220 \mathrm{~B}$ P. Another date at 29,140 \pm 200 B P from an unexcavated layer below this site is consistent with dates from northern Thailand. Laos is located between the two well-documented regions corresponding to modern northern Thailand and Vietnam where lies the historical cradle of the Hoabinhian culture (Colani, 1929a,b). More intensive and systematic prehistoric archaeological research should be undertaken in Laos on that topic. This represents an absolute priority if we are to gain a more precise definition of the Hoabinhian techno-complex and its geographical variations (Gorman, 1969; Reynolds, 1989, 1990; Forestier, 2000; White and Gorman, 1984; Forestier et al., 2005, 2013; Zeitoun et al., 2008). Because, on the one hand, re-excavations provided very little new knowledge due to the lack of stratigraphic analysis and/or methodological shortcomings, and, on the other hand, the new sites only provided preliminary results so far, it is necessary to develop more comprehensive and standardized field investigations. Capacity building in archaeological research has to be promoted and delivered among local students. At this stage, it seems essential to consolidate local knowledge and expertise based on the existing regional background rather than by launching adventurous explorations. Nevertheless, the inventory of rock art sites has to be developed in the same time as it is important to get the support of the interest of the public to exhort the political authorities to support prehistoric research. In this paper, our purpose was only to discuss of the revival of prehistory in Laos as a whole but questions have to be raised concerning the apparent lack of prehistoric sites in the southern part of the country. While at a more modest scale, the situation of archaeological research in Laos shares similarities with that in Cambodia where, for decades, prehistoric studies remained in the shadow of Angkorian studies (Sophady, 2014). Further, the lack of interest and research in southern Laos has been reinforced due to the fact that it has not yet yielded any outstanding sites such as the numerous Iron-aged cemeteries exploited in neighbouring northeast Thailand (Higham, 2002). Geopolitical issues and lack of economic development should be considered as the primary causes of the lack of archaeological and prehistoric research in Laos, rather than a putatively weak potential. The current Asian economic perspectives will certainly help developing international collaborations and exchanges which will have immediate beneficial impacts on prehistoric studies and education in Laos.

\section{Acknowledgments}

Sommay Singthong is grateful to Erasmus Mundus in Quaternary and Prehistory consortium who gave him the opportunity to study in Europe. We thank Claire Gaillard and an anonymous reviewer for their constructive comments.

\section{References}

Anzai, M., 1976. Stone artifacts collected at prehistoric cave sites in Laos. Kokogaku Zasshi 61, 81-82.

Arambourg, C., Fromaget, J., 1938. Le gisement quaternaire de Tam Nang (Chaîne Annamitique septentrionale). Sa stratigraphique et ses faunes. Comptes Rendus de l'Académie des Sciences 203, 793-795. Auetrakulvit, P., Forestier, H., Khaokhiew, C., Zeitoun, V., 2012. New excavation at Moh Khiew site (Southern Thailand). In: Bonatz, D., Reinecke, A., Tjoa-Bonatz, M.-L. (Eds.), Crossing Borders in Southeast Asian Archaeology. NUS Press, Singapore, pp. 62-74.

Bacon, A.-M., 2012. Les sites de Tam Hang, Nam Lot et Tam Pa Ling au nord du Laos. Editions du CNRS, p. 150.

Bouxaythip, S., 2011. The Significant Rock Art in Lao P.D.R. Presented at the Training/Workshop on the introduction to Rock art studies in southeast Asia, Bangkok Thailand, 2-13 may 2011.

Colani, M., 1929a. Quelques pal_eolithes hoabiniens typiques de l'abri sous-roche de Lang Kay. Bulletin de l'Ecole Française d'Extrême Orient 26, 353-384.

Colani, M., 1929b. Quelques stations hoabinhiennes (note préliminaire). Bulletin de l'Ecole Française d'Extrême-Orient 29, 261-272.

Colani,M., 1932. Champs de jarresmonolithiques et de pierres fun_eraire du Tran-ninh (Haut Laos). In: Praehistorica Asiae Orientalis premier congré des préhistoriens d'Extrême-Orient. Imprimerie d'ExtrêmeOrient, Hanoi, pp. 103-128. 
Colani, M., 1935. Mégalithes du Haut Laos (Hua Pan, Tran Ninh). Publication de l'Ecole Française d'Extrême Orient 25-26, Paris, p. 629.

Demeter, P., 2000. Histoire du peuplement humain de l'Asie extrême orientale depuis le Pléistocène supérieur récent (Thesis of University of Paris I).

Demeter, P., Sayavongkhamdy, T., Patole-Edoumba, E., Coupey, A.-S., 2009. Tam Hang rockshelter: preliminary study of a prehistoric site in Northern Laos. Asian Perspectives 48, 291-308.

Forestier, H., 2000. Chaînes op_eratoires lithiques en Asie du Sud-Est au Pléistocène supérieur final et au début de l'Holocène. L'Anthropologie 104, 531-548.

Forestier, H., Sophady, H., Puaud, S., Celiberti, V., Fr_ere, S., Zeitoun, V., Mourer- Chauvirè, C., Mourer, R., Than, H., Billault, L., 2015. The Hoabinhian from Laang Spean cave in its stratigraphic, chronological, typo-technological and environmental context (Cambodia, Battambang province). Journal of Archaeological Sciences: Reports 3, 194-206.

Forestier, H., Zeitoun, V., Seveau, A., Driwantoro, D., Winayalai, C., 2005. Prospections paléolithiques et perspectives technologiques pour redéfinir le Hoabinhien du nord de la Thailande (campagnes 2002-2005). Aséanie 15, 33-60.

Forestier, H., Zeitoun, V., Winayalai, C., Maitay, C., 2013. The open-air site of Huai Hin (Northwestern Thailand): chronological perspectives for the Hoabinhian. Comptes rendues Palevol 12, 45-55.

Fromaget, J., 1937a. Etudes géologiques sur le nord ouest du Tonkin et le nord du haut Laos (première partie). Bulletin du service géologique d'Indochine 23, 101-164.

Fromaget, J., 1934. Observations et réflexions sur la géologie stratigraphique et structurale de l'Indochine. Bulletin du service géologique d'Indochine 4, 101-164.

Fromaget, J., 1936. Sur la stratigraphie des formations récentes de la Chaîne Annamitique septentrionnale et sur l'existence de l'homme dans le Quaternaire inférieur de cette partie de l'Indochine. Comptes Rendus de l'Académie des Sciences 16, 738-741.

Fromaget, J., 1937b. Aperçu sur la Stratigraphie et l'Anthropologie préhistorique des formations récentes dans la Chaîne Annamitique et le Haut-Laos. In: Compte rendu de la douzième session du Congrès préhistorique de France, Toulouse- Foix, pp. 785-798.

Fromaget, J., 1940a. Les r_ecentes d_ecouvertes anthropologiques dans les formations préhistoriques de la chaine annamitique. In: Proceedings of the Third Congress of Prehistorians of the Far East, Singapore 1938, pp. 51-59.

Fromaget, J., 1940b. La stratigraphie des dépôts préhistoriques de Tam Hang (Chaîne Annamitique septentrionale) et ses difficultés. In: Proceedings of the Third Congress of Prehistorians of the Far East, Singapore 1938, pp. 60-70.

Fromaget, J., 1941. L'Indochine française sa structure, ses roches ses mines et leurs relations possibles avec la tectonique. Bulletin du service géologique d'Indochine 26, 1-140.

Fromaget, J., 1952. Etudes géologiques sur le nord ouest du Tonkin et le nord du haut Laos (première partie). Bulletin du service géologique d'Indochine 19, 1-198.

Fromaget, J., Saurin, E.,1936. Note préliminaire sur les formations cénozoïques et plus récentes de la chaîne annamitique septentrionale du haut Laos. Stratigraphie, préhistoire, anthropologie. Bulletin du service géologique d'Indochine 22, 7-48.

Gorman, C., 1969. Hoabinhian: a pebble tool complex with early plant associations in Southeast Asia. Science 163, 671-673.

Higham, C., 2002. Early Cultures of Mainland Southeast Asia. River Books, Bangkok.

Kuzmin, Y., Keates, S., 2014. Direct radiocarbon dating of Late Pleistocene hominids in Eurasia: current status, problems and perspectives. Radiocarbon 56, 753-766.

Mansuy, H., 1920. Contributions à l'étude de l'Indochine. I. L'industrie de la pierre et du bronze dans la région de Luang Prabang (Haut-Laos), vol. 7. Imprimerie d'Extrême-Orient, Bulletin du service géologique d'Indochine, Hanoi, p. 14.

Marwick, B., White, J.C., Bouasisengpaseuth, B., 2009. The Middle Mekong archaeology project and international collaboration in Luang Prabang, Laos. The SAA Archaeological Record 9 (3), 25-27.

Massie, M., 1904. Catalogues des objets des âges de la pierre et du bronze recueillis dans la région de Luang Prabang. In: Pavie, E., Leroux (Eds.), Mission Pavie Indochine 1879-1895. Recherches sur l'histoire naturelle de l'Indochine orientale, pp. 10-16.

Olsen, J., Ciochon, R., 1990. A review of evidence for postulated Middle Pleistocene occupations in Viet Nam. Journal of Human Evolution 19, 761-788.

Phaboudy, S., 2009. Teaching Material on Archaeological Sites in Laos. Unpublished paper of Faculty of 
Social Sciences. National University of Laos, pp. 17-22.

Pierret, A., Zeitoun, V., Forestier, H., 2012. Doubts upon the status of Tam Pa Ling fossil. Proceedings, National Academy of Science 109, E3523. http://dx.doi.org/10.1073/pnas.1216774109.

Raymaekers, P., 2001. Prospection archéologique de la vallée laotienne du fleuve Mékong. British Archaeological Reports International series 972. Archeopress, Oxford.

Reynolds, T., 1989. Techno-typology in Thailand: a case study of Tham Khao Khi Chan. Bulletin of the Indo-Pacific Prehistory Association 9, 33-43.

Reynolds, T., 1990. Problems in the Stone Age of Thailand. Journal of the Siam Society 78, 109-114.

Saurin, E., 1935. Station néolithique à Na Mou, Province de Luang Prabang (Haut-Laos) (Indochine Française). In: Congrès préhistorique de France, Onzième session, Périgueux 1934, Compte-rendu 11, Paris, pp. 258-266.

Saurin, E., 1966. Le mobilier préhistorique de l'abri-sous-roche de Tam Pong (Haut Laos). Bulletin de la société des études d'Indochine 41, 106-118.

Saurin, E., 1968. Station préhistorique à ciel ouvert dans le massif du Pha Xieng Tong (Laos). In: Solheim II, W. (Ed.), Anthropology at the Eight Pacific Science Congress. Social Science Research Institute, University of Hawaii, Honolulu, pp. 86-95. Asian and Pacific Archaeology Series 2.

Sayavongkhamdy, T., Bellwood, P., Bulbeck, D., 2000. Recent archaeological research in Laos. Bulletin of the Indo-Pacific Prehistory Association 19, 101-110.

Shoocongdej, R., 2006. Late Pleistocene activities at the Tham Lot rockshelter in highland Pang Mapha, Mae Hong Son province, northwestern Thailand. In: Bacus, E., Glover, I., Pigott, V. (Eds.), Uncovering Southeast Asia's Past. Singapore University Press, pp. 22-37.

Sophady, H., 2014. The case of Phnom Teak Treang and Laang Spean cave, Cambodia: the potential for world heritage site nomination; significance of the site for human evolution in Asia, and the need for international cooperation. In: Sanz, N. (Ed.), World Heritage Papers 39, Heads 3: Human Origin Sites and the World Heritage Convention in Asia, UNESCO, pp. 164-178.

Srisuchat, A., 1996. Rock art news from South-east Asia. In: Bahn, P., Fossati, A. (Eds.), Rock Art Studies News of the World I. Oxbow Books, Oxford, UK, pp. 141-144.

Tan, H.N., 2014. Rock Art research in southeast Asia: a synthesis. Arts 3, 73-104.

Tan, H.N., Taçon, P., 2014. Rock art and sacred landscapes of mainland Southeast Asia. In: Gillette, D., Breen Murray,W., Greer, M., Helen Hayward, M. (Eds.), Rock Art and Sacred Landscapes. Springer Science, New York, pp. 67-84.

White, J.C., Bouasisengpaseuth, B., 2008. Archaeology of the Middle Mekong: introduction to the Luang Prabang exploratory survey. In: Goudineau, Y., Lorrillard, M. (Eds.), Recherches Nouvelles sur le Laos. Ecole Française d'Extrême Orient, Paris, pp. 37-52.

White, J.C., Lewis, H., Bouasisengpaseuth, B., Marwick, B., Arrell, K., 2009. Archaeological investigations in northern Laos: new contributions to Southeast Asian prehistory. Antiquity 83, 1, 319, project gallery.

White, J., Gorman, C., 2004. Patterns in "amorphous" industries: the Hoabinhian viewed through a lithic reduction sequence. In: Paz, V. (Ed.), Southeast Asian Archaeology. University of the Phillipines Press, Quezon City, 411-441.

Yi, S., Lee, J.-J., Kim, S., Yoo, Y., Kim, D., 2008. New data on the Hoabinhian: investigations at Hang Cho cave, Northern Vietnam. Bulletin of the Indo-Pacific Prehistory Association 28, 73-79.

Zeitoun, V., Forestier, H., Nakbunlung, S., 2008. Préhistoires au sud du Triangle d'Or. Editions IRD, Paris, p. 252.

Zeitoun, V., Forestier, H., Pierret, A., Chiemsiouraj, C., Lorvankham, M., 2012. Multimillenary occupation in Northwestern Laos: preliminary results of excavations at the Ngeubhinh Mouxeu rock-shelter. Comptes rendus Palevol 11, 305-313. 